\title{
The Gas Phase Oxide and Oxyhydroxide Chemistry of Trace Amounts of Rhenium
}

\author{
By R. Eichler ${ }^{1, *}$, B. Eichler ${ }^{2}$, H. W. Gäggeler ${ }^{1,2}$, D. T. Jost ${ }^{2}$, R. Dressler ${ }^{2}$ and A. Türler ${ }^{2}$ \\ 1 Department of Chemistry and Biochemistry, University of Bern, Freiestr. 3, CH-3012 Bern, Switzerland \\ 2 Paul-Scherrer-Institute, CH-5232 Villigen, Switzerland
}

(Received June 22, 1999; accepted in revised form October 19, 1999)

Rhenium / Thermochromatography / OLGA / Oxide / Oxyhydroxide / Adsorption

\section{Summary standard state for the simple gas adsorption process:

$$
\begin{aligned}
& \mathrm{X}(\mathrm{g}) \rightleftharpoons \mathrm{X}(\mathrm{ads}) \quad\left(\mathrm{X}=\mathrm{ReO}_{3}, \mathrm{HReO}_{4}\right) \\
& \Delta \mathrm{H}_{\mathrm{ads}}\left(\operatorname{ReO}_{3}\right)=-190 \pm 10 \mathrm{~kJ} / \mathrm{mol} ; \\
& \Delta \mathrm{S}_{\mathrm{ads}}\left(\operatorname{ReO}_{3}\right)=-179 \pm 30 \mathrm{~J} / \mathrm{mol} \mathrm{K} ; \\
& \Delta \mathrm{H}_{\mathrm{ads}}\left(\mathrm{HReO}_{4}\right)=-77 \pm 5 \mathrm{~kJ} / \mathrm{mol} ; \\
& \Delta \mathrm{S}_{\mathrm{ads}}\left(\mathrm{HReO}_{4}\right)=-187 \pm 50 \mathrm{~J} / \mathrm{mol} \mathrm{K}
\end{aligned}
$$

In preparation of experiments to investigate the chemical properties of bohrium (Bh, element 107) the behaviour of $\mathrm{Re}$, its lighter homologue in group 7 , was studied in different oxidizing chemical systems. The adsorption data of Re oxide and oxyhydroxide compounds on quartz surfaces were evaluated from results of thermochromatography experiments and confirmed in isothermal gas chromatography experiments applying $1 \mathrm{~cm}$ as

An on-line separation method for oxides and oxyhydroxides of short lived Re isotopes using isothermal high temperature gassolid adsorption chromatography was developed. Separation yields and times of group 7 elements from lanthanides (model for actinides), polonium and bismuth were determined using the model isotopes ${ }^{169,170,174,176} \mathrm{Re},{ }^{152-155} \mathrm{Er},{ }^{151-154} \mathrm{Ho},{ }^{218} \mathrm{Po}$, and ${ }^{214} \mathrm{Bi}$. An updated correlation function between the microscopic adsorption enthalpy and the macroscopic sublimation enthalpy was calculated from the experimental adsorption data of this work and literature data.

\section{Introduction}

The growing use of the nuclides ${ }^{186,188} \mathrm{Re}$ in modern nuclear medicine requires the development of production methods and of fast and efficient separation techniques for radioactive Re nuclides [1]. Therefore, the knowledge of the inorganic and complex chemistry of this element is very essential. The behaviour of simple inorganic $R e$ compounds is interesting too for a completely different field of chemistry - the chemical characterization of the heaviest elements. Of the currently 10 known transactinide elements $(Z>103)$ only the first three, namely rutherfordium ( $R f$, element 104), dubnium ( $\mathrm{Db}$, element 105) and seaborgium (element 106) have been chemically characterized. The main goal of a chemical characterization of

\footnotetext{
* Author for correspondence

(E-mail: Robert.Eichler@psi.ch).
}

transactinide elements is their placement in the Periodic Table. Due to the high nulear charge (Z), relativistic effects are strongly influencing the electronic structure of these elements [2,3]. Relativistic effects affect also the binding energies of the valence electrons and thus the symmetry of the atomic orbitals, which determine the chemical behaviour of the transactinides. Thus, these effects may disturb the periodicity of properties in the transition metal groups of the Periodic Table. In extreme cases they might even change chemical properties to such an extent that the heavy elements behave no longer similar to their lighter homologues. In recent experiments the gas chemical behaviour of the first transactinide elements rutherfordium $\operatorname{Rf}[4,5], \mathrm{Db}[6,7]$ and $\mathrm{Sg}[8,9]$ was determined at an "one-atom-at-a-time" level using the on-line separation and detection technique OLGA [14]. Evidence for relativistic effects was observed in the behaviour of Rf-chlorides [4]. Most recently, experiments on the chemistry of seaborgium showed that $\mathrm{SgO}_{2} \mathrm{Cl}_{2}$ behaved similar to $\mathrm{WO}_{2} \mathrm{Cl}_{2}[8]$.

Experiments to determine for the first time the chemical behaviour of bohrium (Bh, element 107) are envisaged. All known Bh isotopes have been produced in so-called cold fusion reactions with $\mathrm{Pb}$ or $\mathrm{Bi}$ targets and are therefore neutron deficient and very shortlived $\left(t_{1 / 2}<1 \mathrm{~s}\right)$, which is too short for a study of its chemical properties. More neutron-rich and hence, longer-lived isotopes of $\mathrm{Bh}$ could be produced in hot fusion reactions. The expected half-lives of e.g. ${ }^{266 / 267} \mathrm{Bh}$ are in the order of a few seconds $[10,11]$. These isotopes can be produced in the reaction ${ }^{249} \mathrm{Bk}\left({ }^{22} \mathrm{Ne} ; 4,5 \mathrm{n}\right){ }^{266,267} \mathrm{Bh}$. The production cross sections are estimated to be in the order of $50 \mathrm{pb}$. Thus, the experimental determination of physico-chemical properties of $\mathrm{Bh}$ compounds requires the development of fast, efficient and at the same time selective separation techniques.

A first attempt of an experimental characterization of the chemical properties of Bh was carried out by Zvara et al. [12]. At the JINR, Dubna an attempt was made to produce $\mathrm{Bh}$ nuclides in the reaction ${ }^{249} \mathrm{Bk}\left({ }^{22} \mathrm{Ne} ; 4-6 \mathrm{n}\right){ }^{265-267} \mathrm{Bh}$. After a thermochromatography separation of volatile oxyhydroxides in the chemical system air/ $\mathrm{H}_{2} \mathrm{O}$ an off-line search for spontaneous fission (sf) tracks in the thermochromatography column was performed. No fission tracks related 
to Bh nuclides were detected. This negative result was interpreted that either the half-lives of the produced $\mathrm{Bh}$ nuclides were shorter than $2 \mathrm{~s}$ or that the production cross section was less than $100 \mathrm{pb}$. In another attempt at LBNL Berkeley, Schädel et al. [13] used the reaction ${ }^{254} \mathrm{Es}\left({ }^{16} \mathrm{O} ; 3-5 \mathrm{n}\right){ }^{265-267} \mathrm{Bh}$. The reaction products were transported by a $\mathrm{He}-\mathrm{KCl}$ gas jet to an online gas chromatography apparatus (OLGA) [14]. A reactive gas mixture of $\mathrm{O}_{2} / \mathrm{H}_{2} \mathrm{O}$ was added. The volatile $\mathrm{Bh}$-oxyhydroxides were separated from heavy actinides and lighter transactinide elements and then condensed on $\mathrm{Ni} / \mathrm{Ta}$ foils for on-line $\alpha$-particle and sf spectroscopy. No genetically linked decay chains were detected. Either the half-lives of the produced Bh-nuclides were shorter than $2 \mathrm{~s}$ or the production cross section was less than $5 \mathrm{nb}$. In both experiments no chemical properties of Bh could be determined.

In order to attempt a chemical characterization of $\mathrm{Bh}$, the behaviour of Re, its closest lighter homologue, was studied in this work. The formation and gas chromatographic separation of $\mathrm{ReO}_{3}$ and $\mathrm{HReO}_{4}$ was investigated on-line using short-lived $R e$ isotopes.

\section{Thermochemistry of the Oxid/Oxyhydroxide compounds of $R e$}

The formation of oxides and oxyhydroxides in $\mathrm{O}_{2} /$ $\mathrm{H}_{2} \mathrm{O}$-containing gas chemical systems is typical for the group 7 elements and has extensively been studied [15-23]. Due to their high volatility the oxyhydroxides are especially interesting for gas chromatography studies, since a high volatility of the investigated compound allows high separation factors from less volatile by-products, such as heavy actinides, $\mathrm{Po}, \mathrm{Pb}$, and $\mathrm{Bi}$, which usually hamper detection of final products by $\alpha$-spectroscopy. Thermodynamic data (see Table 1) indicate, that for carrier-free amounts of rhenium in a $\mathrm{O}_{2} / \mathrm{H}_{2} \mathrm{O}$ containing gas phase system, $\mathrm{ReO}_{3}$ and $\mathrm{HReO}_{4}$ are the only stable volatile species. The thermodynamically most stable molecule in this chemical system at standard conditions ( $298 \mathrm{~K}, 1 \mathrm{~atm})$ is $\mathrm{HReO}_{4}$, the perrhenic acid.

\section{Experimental}

\subsection{Investigations in the temperature gradient tube}

Thermochromatography is a very suitable gas adsorption chromatographic separation method. It has been successfully applied to characterize the behaviour of various compounds in different chemical systems $[18-24,48,49,54]$.

\subsubsection{Experiments with carrier free Re}

The formation and the volatility of $\mathrm{ReO}_{3}$ and $\mathrm{HReO}_{4}$ in $\mathrm{He} / \mathrm{O}_{2} / \mathrm{H}_{2} \mathrm{O}$ atmosphere were investigated by thermochromatography using carrier free ${ }^{183 / 184} \mathrm{Re}$. The
Table 1. Thermodynamical formation data of carrier free $\mathrm{Re}$ compounds in the chemical system $\mathrm{O}_{2} / \mathrm{H}_{2} \mathrm{O} / \mathrm{Re}\left({ }^{*}\right.$ used in this work).

\begin{tabular}{|c|c|c|c|}
\hline Formula & $\Delta_{\mathrm{f}} \mathrm{H}^{0}{ }_{298}[\mathrm{~kJ} / \mathrm{mol}]$ & $\mathrm{S}_{298}^{0}[\mathrm{~J} / \mathrm{molK}]$ & Lit.: \\
\hline $\operatorname{Re}(s)$ & 0 & 36.53 & [25] \\
\hline $\operatorname{Re}(g)$ & $\begin{array}{l}762.3 \\
770.2 \\
776.0\end{array}$ & $\begin{array}{l}190.26 \\
188.92 \\
192.4\end{array}$ & $\begin{array}{l}{[25]} \\
{[26]} \\
{[27]}\end{array}$ \\
\hline $\operatorname{ReO}(s)$ & $\begin{array}{l}-604.6 \\
-255.4\end{array}$ & 44.37 & $\begin{array}{l}{[28]} \\
{[29]}\end{array}$ \\
\hline $\operatorname{ReO}(g)$ & $\begin{array}{l}393.4 \\
376.7 \\
397.7\end{array}$ & $\begin{array}{l}248 \\
242.42\end{array}$ & $\begin{array}{l}{[28]} \\
{[27]} \\
{[29]}\end{array}$ \\
\hline $\mathrm{ReO}_{2}(\mathrm{~s})$ & $\begin{array}{l}-442.2 \\
-422.8 \\
-430.3 \pm 20.0 \\
-423.6 \\
-451.5 \\
-433.9 \\
-447.9 \\
-451.8\end{array}$ & $\begin{array}{l}46.44 \\
41 \\
56.51 \pm 6.7 \\
\\
47.82 \\
\\
56.51 \\
56.52\end{array}$ & $\begin{array}{l}{[25]} \\
{[31]} \\
{[32]} \\
{[34]} \\
{[37]} \\
{[36]} \\
{[29]} \\
{[41]}\end{array}$ \\
\hline $\mathrm{ReO}_{2}(\mathrm{~g})$ & $\begin{array}{l}274.8 \\
58.6 \pm 33.5 \\
88.5 \\
274.6 \\
242.8\end{array}$ & 267.90 & $\begin{array}{l}{[25]} \\
{[30]} \\
{[31]} \\
{[36]} \\
{[29]}\end{array}$ \\
\hline $\mathrm{ReO}_{3}(\mathrm{~s})$ & $\begin{array}{l}-594.3^{*} \\
-611.2 \\
-611.6 \pm 3.4 \\
-605.3 \\
-602.5 \pm 6.3 \\
-601.2 \pm 6.3 \\
-589.1 \pm 3.8 \\
-589.0 \pm 8.4 \\
-592.9 \pm 4.2 \\
-593.2\end{array}$ & $\begin{array}{l}80.75 \\
61.5 \\
69.25 \\
80.79 \pm 6.3 \\
80.79\end{array}$ & $\begin{array}{l}{[25]} \\
{[35]} \\
{[28]} \\
{[31]} \\
{[37]} \\
{[37]} \\
{[36]} \\
{[32]} \\
{[39]} \\
{[29]}\end{array}$ \\
\hline $\mathrm{ReO}_{3}(\mathrm{~g})$ & $\begin{array}{l}-350.6^{*} \\
-326.5 \pm 60 \\
-284.7 \pm 21.0 \\
-280.5\end{array}$ & $\begin{array}{l}339 \\
293 \pm 6 \\
288.7 \pm 8.4^{*} \\
284.65\end{array}$ & $\begin{array}{l}{[25]} \\
{[30]} \\
{[38]} \\
{[29]}\end{array}$ \\
\hline $\mathrm{HReO}_{4}(\mathrm{~s})$ & $\begin{array}{l}-762.7 * \\
-762.7 \pm 4.2 \\
-762.7\end{array}$ & 158.23 & $\begin{array}{l}{[26]} \\
{[40]} \\
{[31]}\end{array}$ \\
\hline $\mathrm{HReO}_{4}(\mathrm{~g})$ & $\begin{array}{l}-665.6 \\
-665.6^{*}\end{array}$ & $313.95 *$ & $\begin{array}{l}{[31]} \\
{[40]}\end{array}$ \\
\hline
\end{tabular}

nuclides ${ }^{183 / 184}$ Re were produced at the PSI Philips Cyclotron by proton irradiation of natural tungsten in the reaction ${ }^{\text {nat }} \mathrm{W}(\mathrm{p} ; \mathrm{xn})^{184,183} \mathrm{Re}$ at a beam energy of $30 \mathrm{MeV}$ [42]. The products were separated from macroamounts of tungsten by thermochromatography [43]. A carrier-free solution of ${ }^{183 / 184} \mathrm{Re}$ was obtained by leaching the thermochromatography column with concentrated ammonia solution. The preparation of a sample of carrier-free ${ }^{183 / 184} \mathrm{Re}$ suitable for a thermochromatography experiment involved the following steps. First, quartz filter stripes were drenched 


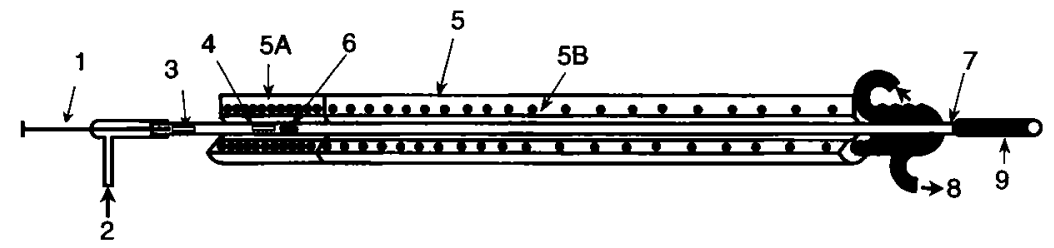

Fig. 1. Thermochromatography set-up: 1 - steel rod; 2 - carrier gas mixture $\mathrm{He} / \mathrm{O}_{2} / \mathrm{H}_{2} \mathrm{O}\left(\mathrm{H}_{2} \mathrm{O}_{2}\right) ; 3-{ }^{183 / 184} \mathrm{Re}$ on quartz filter stripe before starting experiment; $4-{ }^{183 / 184} \mathrm{Re}$ on quartz filter stripe in the reaction oven after starting experiment; 5 - thermochromatography oven with $5 \mathrm{~A}$-reaction oven $1430 \mathrm{~K}$ and $5 \mathrm{~B}$-temperature gradient; 6 - quartz wool plug; 7 - quartz column (i.d. $3 \mathrm{~mm}$, $\mathrm{I}=1 \mathrm{~m}) ; 8$ - cooling spiral; 9 - char coal trap.

with the ammonia leaching solution $\left(\mathrm{NH}_{4}{ }^{183 / 184} \mathrm{ReO}_{4}\right)$ and then dried in a desiccator. Each of the dry quartz filter stripes was placed into a thermochromatography column (i.d. $3 \mathrm{~mm}$ ). The entire column was heated to $1273 \mathrm{~K}$ for $15 \mathrm{~min}$ with a mixture of argon and hydrogen (Vol.-\% ratio $94: 6$, flow rate $100 \mathrm{ml} / \mathrm{min}$ ) in order to reduce the $\mathrm{NH}_{4}{ }^{183 / 184} \mathrm{ReO}_{4}$ to elemental Re. The column with the reduced rhenium sample was placed into a thermochromatography set-up at a position outside the reaction oven (Fig. 1). The $\mathrm{He} / \mathrm{O}_{2}$ mixture was dried with concentrated sulfuric acid followed by a molecular sieve and a cold trap kept at $198 \mathrm{~K}$. A well defined partial pressure of $\mathrm{H}_{2} \mathrm{O}$ was established by saturating the dry gas with water or ice kept at selected temperatures $\mathrm{T}_{\text {sat }}$. A stable temperature gradient along the column was then established in the flowing carrier gas. The gas flow rates were varied between 25 and $1210 \mathrm{ml} / \mathrm{min}$. Every experiment was started by pushing the quartz filter stripe into the hot reaction zone of the thermochromatography oven with a steel rod. After a given time the carrier gas flow was stopped and the quartz column was immediately removed from the oven through the cold end. The distribution of the Reactivity along the quartz column was measured with a HPGe- $\gamma$-detector using a lead collimator with a window size of $1.0 \times 0.6 \mathrm{~cm}$. The experiments were usually repeated several times.

\subsubsection{Experiments with macroscopic amounts}

The behaviour of macroscopic amounts of Re was studied by adding about $1 \mathrm{mg}$ of $\operatorname{Re}_{2} \mathrm{O}_{7}$ carrier to the $\mathrm{NH}_{4}{ }^{183 / 184} \mathrm{ReO}_{4}$ solution. The $\mathrm{Re}$ containing samples were again reduced to elemental $\mathrm{Re}$ using an $\mathrm{Ar} / \mathrm{H}_{2}$ (Vol.-\% 98:2) mixture at $1273 \mathrm{~K}$. For these thermosublimatography experiments the same set-up (Fig. 1) as for the thermochromatography experiments was used.

\subsection{Isothermal gas chromatography}

Based on the thermochromatography studies an online method for the investigation of the adsorption behaviour of oxide compounds of short-lived nuclides on quartz surfaces was developed.

So far, the OLGA-technique has been successfully applied to investigate the oxychloride and chloride chemistry of $\mathrm{Rf}, \mathrm{Db}$, and $\mathrm{Sg}$ [4-8]. Using an aerosol gas-jet transport system, this technique allows an efficient on-line coupling to a production system (the target chamber at an accelerator). It provides a rapid separation of volatile compounds and can be connected directly to a high efficiency $\alpha$-(sf)-detection system like ROMA (ROtating wheel Multidetection Analyser) or the PSI Tape Detection System - using a reclustering gas-jet technique [45].

The nuclide ${ }^{169 m} \mathrm{Re}$ with a half-life of $16 \mathrm{~s}$ and its $\alpha$-decay branch $\left(\mathrm{E}_{\alpha}=5.0 \mathrm{MeV}\right)$ is ideally suited to model the behaviour of the heavier group 7 element Bh. At the PSI Philips Cyclotron ${ }^{169} \mathrm{me}$ was produced in the heavy ion fusion reaction ${ }^{156} \mathrm{Dy}\left({ }^{19} \mathrm{~F} ; 6 \mathrm{n}\right){ }^{169 \mathrm{~m}} \mathrm{Re}$ at a ${ }^{19} \mathrm{~F}$-beam energy of $128 \mathrm{MeV}$. The target material, enriched in ${ }^{156}$ Dy $(20 \%)$, also contained the other stable Dy isotopes ${ }^{158} \mathrm{Dy}(0.51 \%),{ }^{160} \mathrm{Dy}(3.46),{ }^{161} \mathrm{Dy}$ (19.82\%), ${ }^{162}$ Dy (22.19\%), ${ }^{163}$ Dy (16.92\%), and ${ }^{164} \mathrm{Dy}$ (16.25\%) from which the $\gamma$-emitting isotopes ${ }^{170} \mathrm{Re}$ $\left(\mathrm{t}_{1 / 2}=9.2 \mathrm{~s}\right),{ }^{172} \operatorname{Re}\left(\mathrm{t}_{1 / 2}=16 \mathrm{~s}\right),{ }^{172 \mathrm{~m}} \operatorname{Re}\left(\mathrm{t}_{1 / 2}=55 \mathrm{~s}\right)$, ${ }^{174} \operatorname{Re}\left(t_{1 / 2}=2.4 \mathrm{~min}\right)$, and ${ }^{176} \operatorname{Re}\left(\mathrm{t}_{1 / 2}=5.6 \mathrm{~min}\right)$ were produced. Different lanthanide nuclides, produced in transfer reactions of the ${ }^{19} \mathrm{~F}$-beam with the Dy target, such as ${ }^{152-155} \mathrm{Er}$ and ${ }^{151-154} \mathrm{Ho}$, served as model elements for the behaviour of actinides.

In the target chamber, the fusion products were attached to carbon aerosol particles $\left(5 * 10^{6}\right.$ particles/ $\mathrm{cm}^{3}$ ), which were generated by spark discharge in a mixture of $1 \mathrm{l} / \mathrm{min} \mathrm{He}$ and $10 \mathrm{ml} / \mathrm{min} \mathrm{N}_{2}$ and then transported through a steel capillary $(50 \mathrm{~m}$, i.d. $2 \mathrm{~mm})$ to the OLGA set-up. In order to obtain $\mathrm{HReO}_{4} 100 \mathrm{ml} /$ min $\mathrm{O}_{2}$ (containing $500 \mathrm{ppm} \mathrm{O}$ ) saturated with $\mathrm{H}_{2} \mathrm{O}_{2}$ at room temperature were added as reagents to the gasjet gas shortly before the reaction oven. The carbon aerosols were stopped on a quartz wool plug at $1373 \mathrm{~K}$ in the reaction oven, where they were burned to $\mathrm{CO}_{2}$ and the nuclear reaction products were oxidized. Volatile compounds were evaporated and chromatographically separated in a $1.5-2 \mathrm{~m}$ long (i.d. $1.3 \mathrm{~mm}$ ) quartz column kept at variable isothermal temperatures. The time required for compounds to pass through the column at defined isothermal temperatures depends mainly on the adsorption behaviour on the quartz surface and on the gas flow rate. Thus, highly volatile Recompounds pass through the column much faster compared to less volatile compounds of other nuclides which - depending on the isothermal temperature are retained and decay inside the column. Volatile compounds leaving the exit of the column were reat- 


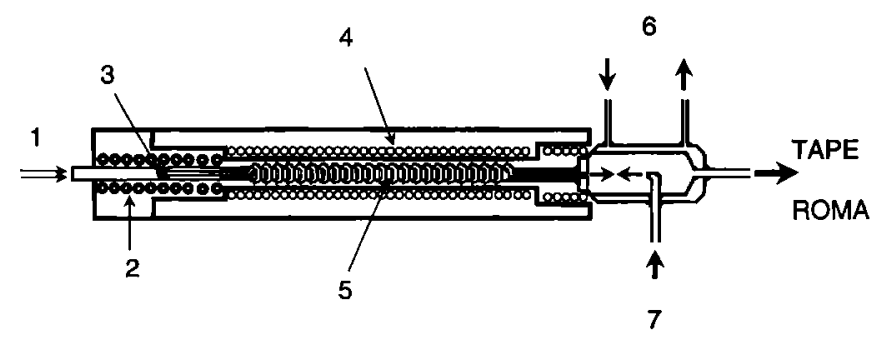

Fig. 2. Modified OLGA III - a high temperature isothermal gas chromatography set-up: $1-\mathrm{O}_{2}\left(\mathrm{O}_{3}\right) / \mathrm{H}_{2} \mathrm{O}\left(\mathrm{H}_{2} \mathrm{O}_{2}\right)$, aerosol gas-jet $\mathrm{He} /$ C; 2 - reaction oven $1400 \mathrm{~K} ; 3$ - quartz wool; 4 - isothermal oven $550-1200 \mathrm{~K} ; 5$ - quartz column with reclustering unit; 6 - water cooling/heating $260-370 \mathrm{~K} ; 7$ - reclustering aerosol gas-jet $\mathrm{Ar} / \mathrm{MoO}_{3}$.

tached to $\mathrm{MoO}_{3}$-aerosols in $1 \mathrm{l} / \mathrm{min} \mathrm{Ar}$ in the reclustering unit and transported to the PSI tape detection system. Here, the $\mathrm{MoO}_{3}$-aerosols were deposited by impaction on the surface of a tape which periodically moved the collected samples in front of a series of PIPS detectors to measure the $\alpha$-decay of ${ }^{169 m} \mathrm{Re}$, ${ }^{152-155} \mathrm{Er}$ and ${ }^{151-154} \mathrm{Ho}$. In position $1 \mathrm{a} \mathrm{HPGe}$-detector registered $\gamma$-rays of ${ }^{170,172,172 m, 174,176} \mathrm{Re}$.

A modified high temperature OLGA III system with an isothermal temperature range between 500 and $1200 \mathrm{~K}$ (Fig. 2) was developed and applied in another experiment to study the formation and the behaviour of less volatile $\mathrm{ReO}_{3}$. As carrier gas mixture $1 \mathrm{l} / \mathrm{min}$ $\mathrm{He}, 10 \mathrm{ml} / \mathrm{min} \mathrm{N}_{2}$ (gas jet mixture) and $100 \mathrm{ml} / \mathrm{min} \mathrm{O}_{2}$ (reactive gas) was used. With this set-up and the same carrier gas conditions, the behaviour of $\mathrm{Po}$ and $\mathrm{Bi}$ was also investigated using the nuclides ${ }^{218} \mathrm{Po}\left(\mathrm{t}_{1 / 2}=\right.$ $3.05 \mathrm{~min})$ and ${ }^{214} \mathrm{Bi}\left(\mathrm{t}_{1 / 2}=19.9 \mathrm{~min}\right)$ from a ${ }^{226} \mathrm{Ra}$ source.

\section{Results and discussion}

4.1 Investigation of the formation and the volatility of rhenium compounds

\subsubsection{Thermochromatography with carrier-free ${ }^{183 / 184} \mathrm{Re}$}

Using $25 \mathrm{ml} / \mathrm{min} \mathrm{He}$ containing 0.001 volume- $\% \mathrm{O}_{2}$ and a water partial pressure $p_{\mathrm{H}_{2} \mathrm{O}}<600 \mathrm{~Pa}$ as carrier gas (Table 2, exp. 4, 9, 12, 15, 16), a single volatile $\operatorname{Re}$ compound was observed that deposited at about $570 \mathrm{~K}$ (Fig. 3, deposition peak $\mathrm{C}$ ) and was attributed to $\mathrm{ReO}_{3}$. About $5 \%$ of the activity remained in the starting zone at about $1430 \mathrm{~K}$ (Fig. 3, deposition peak A) as less volatile species, presumably $\mathrm{ReO}$ or $\mathrm{ReO}_{2}$. Adding more than 5 volume- $\% \mathrm{O}_{2}$ (Table 2) to the carrier gas led to a more volatile compound which deposited at about $340 \mathrm{~K}$ (Fig. 3, deposition peak D), and which was assumed to be $\mathrm{HReO}_{4}$, the most volatile $\mathrm{Re}$ compound in this chemical system. In most cases (Table 2) the formation of both compounds (Fig. 3, deposition peaks $\mathbf{C}$ and $\mathbf{D})$ was observed. To confirm the dependence of the formation of the more volatile $\mathrm{HReO}_{4}$ on the oxidation potential of the carrier gas, $\mathrm{H}_{2} \mathrm{O}_{2}(30 \%)$ was used instead of water in the saturation unit which indeed led to a single peak from $\mathrm{HReO}_{4}$ (Table 2, exp. 13).

The deposition peak at about $340 \mathrm{~K}$ (Fig. 3, deposition peak D), assigned to $\mathrm{HReO}_{4}$, can be explained by a mobile adsorption process:

$$
\mathrm{HReO}_{4} \text { (g) } \rightleftarrows \mathrm{HReO}_{4} \text { (ads) . }
$$

Applying higher gas flow rates (Table 2, exp. 20) a less volatile $\mathrm{Re}$ compound at about $820 \mathrm{~K}$ (Fig. 3, deposition peak B) was observed. With about $50 \% \mathrm{O}_{2}$ in the carrier gas two deposition peaks, $\mathbf{C}$ and $\mathbf{D}$, at lower temperatures (Table 2) were found.

In further experiments (Table 2, exp. 39, 41) the chromatography columns were pretreated with oxygen

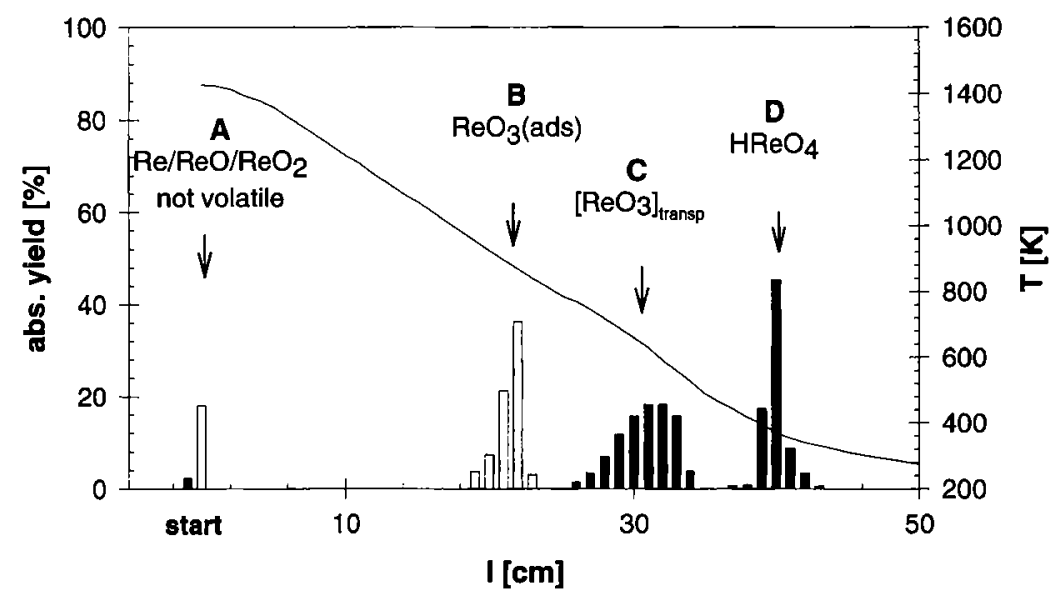

Fig. 3. Merged thermochromatograms of three different experiments (for details see text). 
Table 2. Thermochromatography experiments assigned to mobile adsorption of $\mathrm{HReO}_{4}(\mathrm{D})$ and $\mathrm{ReO}_{3}(\mathrm{~B})$ and to a transport reaction of $\mathrm{ReO}_{3}(\mathrm{C})$ according to: $\mathrm{HReO}_{4}(\mathrm{~g}) \leftrightarrows \mathrm{ReO}_{3}(\mathrm{ads})+1 / 4 \mathrm{O}_{2}+1 / 2 \mathrm{H}_{2} \mathrm{O}$.

\begin{tabular}{|c|c|c|c|c|c|c|c|c|c|}
\hline \multirow[t]{2}{*}{ Exp. } & \multirow{2}{*}{$\begin{array}{c}\text { Starting } \\
\text { temperature } \\
T_{s}[K]\end{array}$} & \multirow[t]{2}{*}{$\begin{array}{c}\text { Gas flow rate } \\
\mathrm{v}[\mathrm{ml} / \mathrm{min}]\end{array}$} & \multirow{2}{*}{$\begin{array}{c}\text { Experiment } \\
\text { duration } \\
t[\mathrm{~min}]\end{array}$} & \multirow{2}{*}{$\begin{array}{c}\text { Temperature } \\
\text { in the saturation } \\
\text { unit with } \mathrm{H}_{2} \mathrm{O} \\
\text { or with }{ }^{*} \mathrm{H}_{2} \mathrm{O}_{2} \\
\text { Tsat. }[\mathrm{K}]\end{array}$} & \multirow{2}{*}{$\begin{array}{c}\mathrm{O}_{2} \text { content in } \\
\text { the carrier gas } \\
\text { [vol-\%] }\end{array}$} & \multirow{2}{*}{$\begin{array}{c}\text { Temperature } \\
\text { gradient } \\
\mathrm{g}[\mathrm{K} / \mathrm{cm}]\end{array}$} & \multicolumn{3}{|c|}{$\begin{array}{c}\text { Deposition } \\
\text { temperature } T_{d}[K]\end{array}$} \\
\hline & & & & & & & $\mathbf{B}$ & C & D \\
\hline 1 & 1428 & 25 & 5 & 293 & 60 & 27.3 & - & 580 & 325 \\
\hline 2 & 1428 & 25 & 5 & 253 & 60 & 27.3 & - & 603 & 329 \\
\hline 3 & 1428 & 25 & 5 & 253 & 60 & 27.3 & - & 580 & - \\
\hline 4 & 1428 & 25 & 5 & 273 & 0.001 & 27.3 & - & 628 & - \\
\hline 5 & 1428 & 25 & 5 & 253 & 60 & 27.3 & - & 451 & 329 \\
\hline 6 & 1428 & 25 & 5 & 253 & 60 & 27.3 & - & - & 368 \\
\hline 7 & 1428 & 25 & 5 & 253 & 60 & 27.3 & - & 454 & - \\
\hline 8 & 1428 & 25 & 5 & 253 & 100 & 27.3 & - & - & 347 \\
\hline 9 & 1428 & 25 & 5 & 253 & 0.001 & 27.3 & - & 509 & - \\
\hline 10 & 1428 & 25 & 5 & 253 & 4 & 27.3 & - & 505 & 325 \\
\hline 11 & 1428 & 25 & 5 & 253 & 4 & 27.3 & - & 580 & 321 \\
\hline 12 & 1428 & 25 & 5 & 273 & 0.001 & 27.3 & - & 562 & - \\
\hline 13 & 1428 & 25 & 5 & $* 273$ & 0.001 & 27.3 & - & - & 349 \\
\hline 14 & 1428 & 500 & 30 & 273 & 50 & 26.6 & - & - & 293 \\
\hline 15 & 1428 & 500 & 30 & 253 & 0.001 & 26.6 & - & 380 & - \\
\hline 16 & 1428 & 500 & 30 & 253 & 0.001 & 26.6 & - & 367 & - \\
\hline 17 & 1329 & 25 & 60 & 303 & 40 & 11.6 & - & - & 339 \\
\hline 18 & 1329 & 25 & 60 & 303 & 40 & 11.6 & - & - & 335 \\
\hline 19 & 1408 & 1010 & 60 & 253 & 80 & 21.8 & - & 473 & - \\
\hline 20 & 1408 & 1010 & 60 & 303 & 80 & 21.8 & 777 & - & - \\
\hline 21 & 1408 & 1010 & 60 & 303 & 80 & 21.8 & 800 & - & - \\
\hline 22 & 1408 & 1010 & 60 & 303 & 80 & 21.8 & 777 & - & - \\
\hline 23 & 1408 & 830 & 60 & 323 & 20 & 21.8 & - & 549 & - \\
\hline 24 & 1408 & 1000 & 60 & 313 & 100 & 21.8 & - & - & 298 \\
\hline 25 & 1408 & 1610 & 20 & 313 & 50 & 21.8 & 800 & - & 298 \\
\hline 26 & 1408 & 1610 & 20 & 313 & 50 & 21.8 & 824 & - & 298 \\
\hline 27 & 1408 & 1610 & 60 & 293 & 60 & 21.8 & 753 & - & - \\
\hline 28 & 1408 & 1610 & 60 & 293 & 60 & 21.8 & - & 408 & 298 \\
\hline 29 & 1408 & 1610 & 20 & 303 & 50 & 21.8 & 800 & - & - \\
\hline 30 & 1408 & 1010 & 10 & 313 & 50 & 21.8 & 824 & - & 298 \\
\hline 31 & 1408 & 1210 & 10 & 293 & 80 & 21.8 & 847 & - & - \\
\hline 32 & 1408 & 1210 & 10 & 293 & 80 & 21.8 & - & 524 & - \\
\hline 33 & 1408 & 1210 & 5 & 203 & 80 & 21.8 & 823 & - & - \\
\hline 34 & 1408 & 1000 & 5 & 293 & 100 & 21.8 & - & - & 338 \\
\hline 35 & 1408 & 500 & 5 & 293 & 100 & 21.8 & - & - & 333 \\
\hline 36 & 1408 & 500 & 5 & 293 & 100 & 21.8 & - & - & 344 \\
\hline 37 & 1408 & 500 & 5 & 293 & 100 & 21.8 & - & - & 315 \\
\hline 38 & 1273 & 25 & 150 & 77 & 0.007 & 17.6 & - & 506 & - \\
\hline 39 & 1273 & 25 & 60 & 77 & 0.007 & 17.6 & 855 & - & - \\
\hline 40 & 1273 & 25 & 60 & 77 & 0.007 & 17.6 & - & 608 & - \\
\hline 41 & 1273 & 25 & 60 & 77 & 0.007 & 17.6 & 874 & - & - \\
\hline
\end{tabular}

at $1273 \mathrm{~K}$ for $15 \mathrm{~min}$. The $\mathrm{Re}$ samples were reduced in a separate quartz tube and then introduced into the pre-treated thermochromatography columns. Surprisingly, the same high temperature $\operatorname{Re}$ deposition peak B was observed. This deposition was also attributed to $\mathrm{ReO}_{3}$, since the formation of another oxide or oxyhydroxide species of rhenium $\left(\mathrm{ReO}_{x} \mathrm{H}_{y}\right)$ is not probable. This is corroborated by mass spectrometric analyses of rhenium compounds in the $\mathrm{O}_{2} / \mathrm{H}_{2} \mathrm{O}$-gas phase $[32,38]$ and by thermochemical data (see Table 1). In the same set-up experiments (Table 2, exp. 38, 40) with columns heated in $\mathrm{Ar} / \mathrm{H}_{2}$ mixture at $1273 \mathrm{~K}$ led again to a $\mathrm{ReO}_{3}$ deposition at 500-600 K (Fig. 3, deposition peak C). The formation of two deposition peaks of $\mathrm{ReO}_{3}$ could be explained by two different adsorption mechanisms:
- mobile adsorption leading to a $\mathrm{ReO}_{3}$ deposition at 770-870 K (Fig. 3, deposition peak B) which can be described by:

$\mathrm{ReO}_{3}(\mathrm{~g}) \rightleftarrows \mathrm{ReO}_{3}$ (ads);

- a transport reaction where $[15,40,43] \mathrm{ReO}_{3}$ can be transported to lower temperatures $(410-610 \mathrm{~K})$ (Fig. 3, deposition peak $\mathbf{C}$ ) according to:

$$
\begin{aligned}
\mathrm{HReO}_{4}(\mathrm{~g}) \rightleftarrows & \mathrm{ReO}_{3}(\text { ads })+1 / 4 \mathrm{O}_{2}(\mathrm{~g}) \\
& +1 / 2 \mathrm{H}_{2} \mathrm{O}(\mathrm{g}) .
\end{aligned}
$$

It is not possible to describe the real reaction path of the transport process, but the quartz surface has obviously a strong influence on it.

Two independent methods, the model of mobile adsorption [46] and the microscopic model of Zvara 


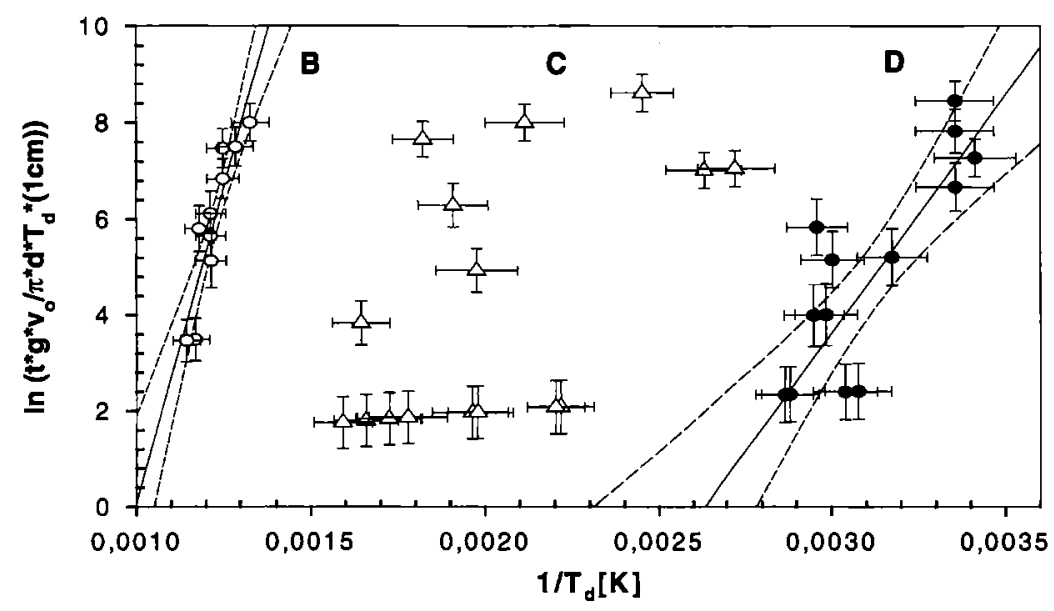

Fig. 4. Experimental adsorption data from Table 2 with either direct formation of (B) $\mathrm{ReO}_{3}$ (open circles) and (D) $\mathrm{HReO}_{4}$ (dots) or with superimposed chemical reaction $(\mathrm{C})\left[\mathrm{ReO}_{3}\right]_{\text {rransp }}$ (triangles).

Table 3. Deposition temperatures $\left(T_{d}\right)$ and evaluated adsorption enthalpies $\left(\Delta \mathrm{H}_{\mathrm{ads}}\right)$ assuming mobile adsorption of $\mathrm{HReO}_{4}, \mathrm{ReO}_{3}$, and of a hypothetical compound $\mathrm{ReO}_{\mathrm{x}} \mathrm{H}_{\mathrm{y}}$. The calculated adsorption enthalpy of $\mathrm{ReO}_{3}$ assuming a transport reaction.

\begin{tabular}{lcc}
\hline Compound & $\mathrm{T}_{\mathrm{d}}[\mathrm{K}]$ & $\Delta \mathrm{H}_{\text {ads }}(298)[\mathrm{kJ} / \mathrm{mol}]$ \\
\hline $\mathrm{HReO}_{4}$ & $346 \pm 20$ & $-77 \pm 5$ \\
$\mathrm{ReO}_{3}$ & $823 \pm 50$ & $-190 \pm 10$ \\
$\mathrm{ReO}_{\mathrm{x}} \mathrm{H}_{\mathrm{y}}$ & $523 \pm 100$ & -120 \\
{$\left[\mathrm{ReO}_{3}\right]_{\text {rransp. }}$} & $523 \pm 100$ & $-220 \pm 30$ \\
\hline
\end{tabular}

[47], were used for the evaluation of the adsorption enthalpies of the compounds from the thermochromatograms (Table 3). By modifying the experimental conditions in thermochromatography over a wide range, the adsorption enthalpy and the adsorption entropy $\left(\Delta \mathrm{H}_{\mathrm{ads}}, \Delta \mathrm{S}_{\mathrm{ads}}\right)$ can be evaluated simultaneously from an Arrhenius plot (Fig. 4). This so-called second law method (4) is the result of a simplified mobile adsorption model proposed in $[46,54]$, which is the only way for an experimental determination of the mobile adsorption entropy of $\mathrm{HReO}_{4}$ and $\mathrm{ReO}_{3}$.

$$
\begin{aligned}
& \ln \frac{t \cdot g \cdot v_{0}}{\pi \cdot d \cdot T_{d} \cdot(1 \mathrm{~cm})}=a \cdot \frac{1}{T_{d}}+b ; \\
& a=\frac{-\Delta H_{a d s}}{R} ; b=\ln \frac{R \cdot T_{0}}{-\Delta H_{a d s}}+\frac{\Delta S_{a d s}}{R} ;
\end{aligned}
$$

$t$ : retention time, experiment time [min]; $g$ : temperature gradient $(\mathrm{g}>0)[\mathrm{K} / \mathrm{m}] ; v_{0}$ : gas flow (STP) $\left[\mathrm{cm}^{3} /\right.$ $\mathrm{min}] ; d$ : inner diameter of the column [mm]; $T_{d}$ : deposition temperature $[\mathrm{K}] ; T_{0}$ : standard temperature $(298.15 \mathrm{~K}) ; R$ : ideal gas constant $(8.314 \mathrm{~J} / \mathrm{mol} \mathrm{K})$; $a, b$ : linear regression parameters.

From the regression parameters of the plot in Fig. 4 the following adsorption properties were evaluated for the reversible adsorption processes (1 and 2):

$$
\begin{aligned}
a(1)= & 9900 \pm 1900 \\
& \Rightarrow \Delta \mathrm{H}_{\text {ads }}\left(\mathrm{HReO}_{4}\right)=-82 \pm 16 \mathrm{~kJ} / \mathrm{mol} ;
\end{aligned}
$$

$$
\begin{aligned}
b(1)= & -26.1 \pm 5.8 \\
& \Rightarrow \Delta \mathrm{S}_{\mathrm{ads}}\left(\mathrm{HReO}_{4}\right)=-187 \pm 50 \mathrm{~J} / \mathrm{mol} \mathrm{K} ; \\
a(2)= & 26000 \pm 3600 \\
& \Rightarrow \Delta \mathrm{H}_{\mathrm{ads}}\left(\operatorname{ReO}_{3}\right)=-216 \pm 30 \mathrm{~kJ} / \mathrm{mol} ; \\
b(2)= & -26.0 \pm 4.4 \\
& \Rightarrow \Delta \mathrm{S}_{\mathrm{ads}}\left(\mathrm{ReO}_{3}\right)=-179 \pm 30 \mathrm{~J} / \mathrm{mol} \mathrm{K} .
\end{aligned}
$$

Using the mobile adsorption model with a superimposed chemical reaction [48] the dissociative adsorption enthalpy and entropy of the transport reaction (3) have been determined:

$$
\begin{aligned}
& \text { and } \Delta \mathrm{H}_{\text {diss.ads }}\left(\mathrm{ReO}_{3}\right)=-23 \pm 30 \mathrm{~kJ} / \mathrm{mol} \\
& \Delta \mathrm{S}_{\text {diss.ads }}\left(\operatorname{ReO}_{3}\right)=-58 \pm 50 \mathrm{~J} / \mathrm{mol} \mathrm{K} .
\end{aligned}
$$

This thermochemical calculation requires a complete set of thermodynamic data of $\operatorname{ReO}_{3}(\mathrm{~g}), \mathrm{ReO}_{3}(\mathrm{~g})$, $\mathrm{ReO}_{3}$ (ads) and $\mathrm{HReO}_{4}(\mathrm{~g})$ (Table 1). Since no literature value for the gas phase entropy of $\mathrm{HReO}_{4}$ existed, an approximated value from [40] was used. The standard formation data of $\mathrm{O}_{2}(\mathrm{~g})$ and $\mathrm{H}_{2} \mathrm{O}(\mathrm{g})$ were taken from [25].

\subsubsection{Thermosublimatography using macroscopic amounts of rhenium}

With macroscopic amounts the gas adsorption chromatography changes to a sublimation chromatography reaching a multilayer coverage of the column surface. Thus, the sublimation enthalpy $\left(\Delta \mathrm{H}_{\text {subl }}\right)$ and sublimation entropy $\left(\Delta \mathrm{S}_{\text {subl }}\right)$ become the describing thermochemical values. The formation of polynuclear compounds is possible. From the thermosublimatograms one can determine the macroscopic property $\Delta \mathrm{H}_{\text {subl }}(5)$ [49].

$$
\ln \frac{m \cdot R \cdot T_{0}}{v_{0} \cdot t \cdot M \cdot p_{0}}=\frac{-\Delta H_{\text {subl }}}{R \cdot T_{d}}+\frac{\Delta S_{\text {subl }}}{R}
$$

$m$ : mass of the compound $[\mathrm{g}] ; p_{0}$ : standard pressure [atm]; $M$ : molar mass of the compound $\left[\mathrm{g} \mathrm{mol}^{-1}\right]$. 


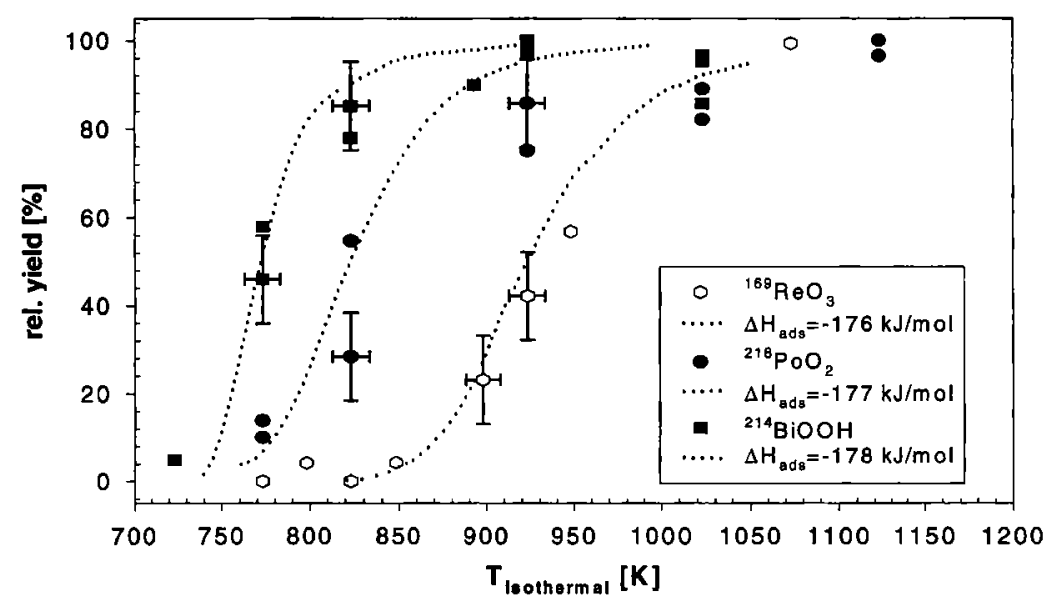

Fig. 5. Temperature vs. yield curves of ${ }^{169} \operatorname{Re}\left(t_{1 / 2}=16 \mathrm{~s}\right.$, presumably $\left.\operatorname{ReO}_{3}\right),{ }^{218} \mathrm{Po}\left(\mathrm{t}_{1 / 2}=3.05 \mathrm{~min}\right.$, presumably $\left.\mathrm{PoO}_{2}\right)$, ${ }^{214} \mathrm{Bi}\left(\mathrm{t}_{1 / 2}=\right.$ $19.9 \mathrm{~min}$, presumably BiOOH) experimental data (symbols) with calculated Monte Carlo simulations (dotted curves) and evaluated adsorption enthalpies.

Table 4. Experimental sublimation enthalpies $\left(\Delta \mathrm{H}_{\text {sub }}(\exp ).\right)$ of $\mathrm{HReO}_{4}, \mathrm{ReO}_{7}$ and $\mathrm{ReO}_{3}$ in comparison to literature data $\left(\Delta \mathbf{H}_{\text {subl }}(\right.$ lit. $\left.)\right)$ together with their deposition temperature ranges $\left(T_{d}\right)$.

\begin{tabular}{lcccc}
\hline Compound & $\mathrm{T}_{\mathrm{d}}$ & $\begin{array}{c}\Delta \mathrm{H}_{\text {sub }} \text { (exp.) } \\
{[\mathrm{kJ} / \mathrm{mol}]}\end{array}$ & $\begin{array}{c}\Delta \mathrm{H}_{\text {sub }} \text { (lit.) } \\
{[\mathrm{kJ} / \mathrm{mol}]}\end{array}$ & \\
\hline (1) $\mathrm{HReO}_{4}$ & $370-380$ & $101 \pm 10$ & 97.1 & {$[31]$} \\
& & & $\begin{array}{r}78.1 \\
{[26]}\end{array}$ & {$[29]$} \\
\hline (2) $\mathrm{Re}_{2} \mathrm{O}_{7}$ & $400-440$ & $132 \pm 10$ & 139.8 & {$[31]$} \\
& & & 147.8 & {$[25]$} \\
\hline (3) $\mathrm{ReO}_{3}$ & $730-740$ & $212 \pm 10$ & 208.4 & {$[34]$} \\
& & & 243.7 & {$[25]$} \\
\hline
\end{tabular}

Using $15 \mathrm{ml} / \mathrm{min} \mathrm{He}$ and $10 \mathrm{ml} / \mathrm{min} \mathrm{O}_{2}$ as carrier gas three compounds were observed that deposited at different temperatures $T_{d}$, independently of the pretreatment of the column: $T_{d}(1)=370-380 \mathrm{~K}, \mathrm{~T}_{\mathrm{d}}(2)=$ $400-440 \mathrm{~K}$ and $T_{d}(3)=730-740 \mathrm{~K}$.

The three compounds in the thermosublimatograms were related to $\mathrm{HReO}_{4}(1), \operatorname{Re}_{2} \mathrm{O}_{7}(2)$, and $\mathrm{ReO}_{3}(3)$ since the evaluated sublimation enthalpies of these compounds $\Delta \mathrm{H}_{\text {subl }}$ (exp.), are in good agreement with the literature data $\Delta \mathrm{H}_{\text {subl }}$ (lit.) (Table 4).

\subsection{Isothermal gaschromatography}

In the isothermal gas chromatographic process the quartz surface is heated in a $\mathrm{He} / \mathrm{O}_{2} / \mathrm{H}_{2} \mathrm{O}(\mathrm{g})$ atmosphere. The separation is carried out applying high gas flow rates. Considering the results of the thermochromatography experiments with carrier-free $R e$ isotopes, neither the transport reaction nor the direct formation reaction of $\mathrm{HReO}_{4}$ can be expected.

Indeed, no $\operatorname{Re}$ isotopes were measured with OLGA III at isothermal temperatures up to $773 \mathrm{~K}$. At the given experimental conditions $\mathrm{HReO}_{4}$ is not formed. A kinetic hindrance of the formation reaction of $\mathrm{HReO}_{4}$ can be excluded, since there was also no longer-lived ${ }^{176} \mathrm{Re}$ observed after chemical separation.

In high temperature isothermal gas chromatography the adsorption behaviour of $\mathrm{ReO}_{3}$ was determined on-line, using the short-lived ${ }^{169,170} \mathrm{Re}$ isotopes. In the temperature range between 720 and $1070 \mathrm{~K}$ the yield of $\mathrm{ReO}_{3}$ as a function of isothermal temperature, has been measured (Fig. 5). The adsorption enthalpy of $\mathrm{ReO}_{3}$ on the quartz surface was evaluated from these curves by a Monte Carlo model to $\Delta \mathrm{H}_{\mathrm{ads}}\left(\mathrm{ReO}_{3}\right)=$ $-176 \pm 10 \mathrm{~kJ} / \mathrm{mol}$ (Fig. 5). This result is in good agreement with the results of the thermochromatography experiments (Table 3) with high gas flow rates or with quartz columns pre-treated with oxygen at $1273 \mathrm{~K}$, where only mobile adsorption of $\mathrm{ReO}_{3}$ leading to a $\mathrm{Re}$ deposition at 750-870 K (Fig. 3, deposition peak B), was found. The overall yields of the gas phase separation were about $60 \%$ for ${ }^{176} \operatorname{Re}\left(\mathrm{t}_{1 / 2}=5.3 \mathrm{~min}\right), 40 \%$ for ${ }^{169} \operatorname{Re}\left(\mathrm{t}_{1 / 2}=16.3 \mathrm{~s}\right)$, and $25 \%$ for ${ }^{170} \operatorname{Re}\left(\mathrm{t}_{1 / 2}=9.2 \mathrm{~s}\right)$. Employing the yield ratio of short-lived ${ }^{169,170} \mathrm{Re}$ and longlived ${ }^{174,176} \mathrm{Re}$ in a so-called "direct catch" (DC) measurement (without chemical separation) and in a gas chemical experiment a separation time of $16 \mathrm{~s}$ was calculated [52]. The formation of $\mathrm{ReO}_{3}$ seems to be kinetically hindered because the transit time of the carrier gas of about $5 \mathrm{~s}$ through the OLGA-system is short in comparison to the determined separation time of $16 \mathrm{~s}$.

Since the isotopes ${ }^{266,267} \mathrm{Bh}$ were expected to have half-lives of about $10 \mathrm{~s}$ only, this gas phase separation system is probably not fast enough for a chemical characterization of $\mathrm{Bh}$.

Another crucial point is the separation efficiency from heavy actinides, which are produced in transfer reactions with high production cross sections, and from $\mathrm{Po}, \mathrm{Pb}$, and $\mathrm{Bi}$ nuclides which are produced in interactions of the heavy ion beam with traces of lead in the target material or the target assembly. These byproducts interfere with an unambiguous identification of $\mathrm{Bh}$ due to their partly very similar $\alpha$-decay energies 


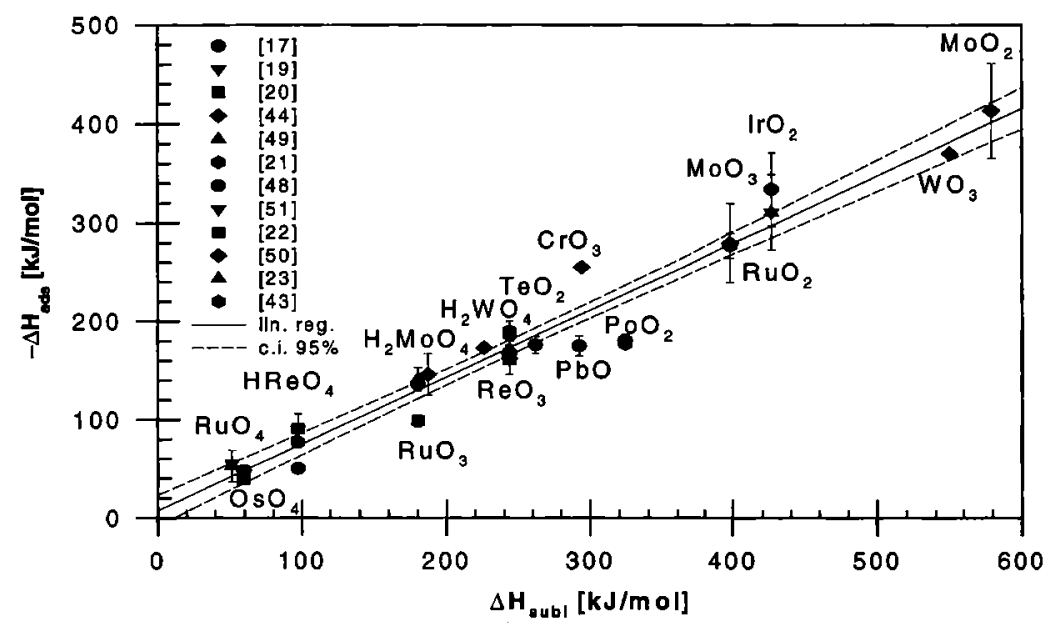

Fig. 6. Updated correlation plot between $\Delta H_{\text {subl }}[\mathrm{kJ} / \mathrm{mol}]$ and $-\Delta \mathrm{H}_{\mathrm{ads}}[\mathrm{kJ} / \mathrm{mol}]$ for the adsorption of oxides and oxyhydroxides on quartz surfaces.

and half-lives and due to spontaneous fissioning heavy actinide nuclei. In the developed high temperature gas chromatography it is not possible to separate Po- and $\mathrm{Bi}$-compounds from the group 7 elements (Fig. 5). The separation of lanthanides as model elements for actinides was evaluated from the total of the $\alpha$-decays of the nuclides ${ }^{152-155} \mathrm{Er}$ and ${ }^{151-154} \mathrm{Ho}$, which were produced in transfer reactions of the ${ }^{19} \mathrm{~F}$ beam with the Dy target. Since no $\alpha$-decays of these nuclides were observed in the $\alpha$-spectra after chemical separation, a separation factor of $\geq 10^{3}$ was deduced.

\subsection{Update of the correlation chart: $\Delta \mathrm{H}_{\mathrm{subl}} /-\Delta \mathrm{H}_{\mathrm{ads}}$}

With regard to our results a re-evaluation of previous thermochromatography experiments with $\operatorname{Re}$ in oxygen and water containing gas systems [17-22, 44] was carried out. At similar experimental conditions Re compounds were observed in these experiments at deposition temperatures near $820 \mathrm{~K}, 520 \mathrm{~K}$, and in the charcoal trap behind the column. In the light of the present experiments these compounds should be assigned to $\mathrm{ReO}_{3},\left[\mathrm{ReO}_{3}\right]_{\text {transp }}$, and $\mathrm{HReO}_{4}$, respectively. Using the model of mobile adsorption with $\Delta \mathrm{S}_{\mathrm{a} \text {,mob }}$ instead of $\Delta S_{\text {subl }}$ [46] and assuming a transport reaction (3) for $\mathrm{ReO}_{3}$, the adsorption enthalpies $\left(\Delta \mathrm{H}_{\mathrm{ads}}(\right.$ lit. $\left.)\right)$ in these experiments can be re-determined $\left(\Delta \mathrm{H}_{\mathrm{ads}}(\right.$ new $)$ or $\left.\Delta \mathbf{H}_{\mathrm{ads}}\left(\left[\mathrm{ReO}_{3}\right]_{\text {ransp }}\right)\right)$. The results of this evaluations for the Re compounds are shown in Fig. 6.

For different gas adsorption systems (e.g. metals [56], oxides [17] and chlorides/oxychlorides [55] on quartz surfaces) empirical linear correlations exist between the microscopic property adsorption enthalpy and the macroscopic sublimation enthalpy. These correlations seem to suggest a similarity of the quartz surface modified by the reactive gas to the surface of the macroscopic solid of the compound which is adsorbed. Using thermodynamic sublimation data $[25,26,41]$, recalculated experimental adsorption data for different oxides and oxyhydroxides, and the determined adsorption data of this work an updated linear correlation (6) was calculated (Fig. 6), resulting in:

$$
\begin{aligned}
& -\Delta \mathrm{H}_{\mathrm{ads}}[\mathrm{kJ} / \mathrm{mol}]=6.271( \pm 7.780) \\
& +0.680( \pm 0.028) * \Delta \mathrm{H}_{\text {subl }}[\mathrm{kJ} / \mathrm{mol}] ; \mathrm{r}^{2}=0.953 .
\end{aligned}
$$

The determination of the adsorption enthalpies of the lighter group 7 species is essential to predict the behaviour of the homologue Bh compounds in the selected chemical system. For this prediction theoretical evaluation of the sublimation enthalpies of the bohrium compounds are important. Since no relativistic $a b$ initio calculations of the electronic structure for the $\mathrm{Bh}$ compounds exist, this evaluation can be made only from a classical thermochemical approach, using trends in the thermodynamic data of homologue compounds within the 7 group. For these predictions in the chemical system of the oxides and oxyhydroxides, additional gaschromatography investigations of Tc are needed.

\section{Conclusions}

In thermochromatography experiments optimum formation conditions for $\mathrm{HReO}_{4}$ and $\mathrm{ReO}_{3}$ and their adsorption properties on quartz surfaces were determined. These conditions were applied in on-line studies with short-lived $R e$ isotopes using isothermal gas adsorption chromatography. The formation of the less volatile $\mathrm{ReO}_{3}$ was observed and its adsorption enthalpy on quartz surfaces was confirmed.

The low volatility of lanthanide (actinide) oxides allow a good separation of $\mathrm{ReO}_{3}$ with good separation factors. However, this is not the case for $\mathrm{Bi}$ and Po, which form oxides or oxyhydroxides of similar volatility as $\mathrm{ReO}_{3}$.

Unfortunately, the more volatile $\mathrm{HReO}_{4}$ which would allow a separation of $\mathrm{Re}$ from $\mathrm{Po}, \mathrm{Pb}$, and $\mathrm{Bi}$, could not be synthesized on-line.

Due to the long separation time (including the time of the formation reaction) the high temperature iso- 
thermal gas chromatography of oxides is applicable for nuclides with half-lives longer than about $10 \mathrm{~s}$.

For the prediction of the behaviour of unknown oxide and oxyhydroxide compounds in the gas chemical system $\mathrm{O}_{2}(\mathrm{~g}) / \mathrm{H}_{2} \mathrm{O}(\mathrm{g}) / \mathrm{SiO}_{2}$ (s) an updated linear correlation function between the microscopic adsorption behaviour of oxide/oxyhydroxide species on quartz surfaces and their macroscopic sublimation enthalpy has been established.

\section{Acknowledgements}

These studies were supported by the Swiss National Science Foundation. We thank Dr. P. A. Schmelzbach and his staff of the PSI Philips Cyclotron for providing intense beams of ${ }^{19} \mathrm{~F}$ and $\mathrm{E}$. Rössler for preparing the ${ }^{156}$ Dy target.

\section{References}

1. Bläuenstein, P.: New J. Chem. 14, 405-407 (1990).

2. Fricke, B., Greiner, W.: Phys. Lett. 30B, 347 (1969).

3. Pershina, V. G.: Chem. Rev. 96, 1977-2101 (1996).

4. Türler, A., Buklanov, G. V., Eichler, B., Gäggeler, H. W., Grantz, M., Hübener, S., Jost, D. T., Lebedev, V. Y., Piguet, D., Timokhin, S. N., Yakushev, A. B., Zvara, I.: J. Alloys and Compounds 271-273, 287-291 (1998).

5. Kadkhodayan, B., Türler, A., Gäggeler, H. W., Hamilton, T. M., Jost, D. T., Kracher, C. D., Kovacs, J., Kreek, S. A., Lane, M. R., Mohar, M. F., Neu, M. P., Stoyer, N. J., Sylwester, E. R., Lee, D. M., Nurmia, M. J., Seaborg, G. T., Hoffman, D. C.: Radiochim. Acta 72, 169-178 (1996).

6. Türler, A., Eichler, B., Jost, D. T., Piguet, D., Gäggeler, H. W., Gregorich, K. E., Kadkhodayan, B., Kreek, S. A., Lee, D. M., Mohar, M., Sylwester, E., Hoffman, D. C., Hübener, S.: Radiochim. Acta 73, 55-66 (1996).

7. Gäggeler, H. W., Jost, D. T., Kovacs, J., Scherer, U. W., Weber, A., Vermeulen, D., Türler, A., Gregorich, K. E., Henderson, R. A., Czerwinski, K. R., Kadkhodayan, B., Lee, D. M., Zimmermann, H. P., Schädel, M., Brüchle, W., Schimpf, E., Zvara, I.: Radiochim. Acta 57, 93 (1992).

8. Gäggeler, H. W.: J. Alloys and Compounds 271-273, 277282 (1998).

9. Schädel, M., Brüchle, W., Dressler, R., Eichler, B., Gäggeler, H. W., Günther, R., Gregorich, K. E., Hoffman, D. C., Hübener, S., Jost, D. T., Kratz, J. V., Paulus, W., Schumann, D., Timokhin, S. N., Trautmann, N., Türler, A., Wirth, G., Yakushev, A. B.: Nature 388, 55-57 (1997).

10. Cwiok, S., Hofmann, S., Nazarewicz, W.: Nucl. Phys. A573, 356 (1994).

11. Lojewski, Z., Baran, A.: Z. Phys. A-Atomic Nuclei 329, $161-167$ (1988).

12. Zvara, I., Domanov, V. P., Hübener, S., Shalaevski, M. R., Timokhin, S. N., Zhuikov, B. L., Eichler, B., Buklanov, G. V.: Radiokhimia 26(1), 76-82 (1984).

13. Schädel, M., Jäger, E., Brüchle, W., Sümmerer, K., Hulet, E. K., Wild, J. F., Lougheed, R. W., Dougan, R. J., Moody, K. J.: Radiochim. Acta 68, 7-12 (1995).

14. Gäggeler, H. W., Jost, D. T., Baltensperger, U., Weber, A., Kovacs, A., Vermeulen, D.: Nucl. Instr. Meth. A309, 201 (1991).

15. Schäfer, H.: Chemische Transportreaktionen, Verlag Chemie, Weinheim (1962).

16. Eichler, B.: Radiochim. Acta 72, 19-26 (1996).
17. Eichler, B., Domanov, V. P.: J. Radioanal. Chem. 28, 143152 (1975).

18. Zhuikov, B. L.: JINR Preprint P12-82-63, Dubna (1982).

19. Bajar, B., Novgorodov, A. F., Vocilka, I., Zaitseva, N. G.: Radiochem. Radioanal. Lett. 19(1), 43-53 (1974).

20. Belov, V. Z., Zvara, I., Korotkin, Y. S., Shalaevski, M. R., Shegolev, W. A., Domanov, V. P.: JINR Preprint P6-6685, Dubna (1972).

21. Steffen, A., Bächmann, K.: Talanta 25, 677-683 (1978).

22. Domanov, V. P.: JINR Preprint P6-81-768 Dubna (1981).

23. Schädel, M., Jäger, E., Schimpf, E., Brüchle, W.: Radiochim. Acta 68, 1-6 (1995).

24. Merinis, J., Boussieres, G.: Radiochim. Acta 12(3), 139 (1969).

25. Knacke, O., Kubaschewski, O., Hesselmann, K.: Thermochemical Properties of Inorganic Substances, 2nd ed., Springer-Verlag, Berlin (1991).

26. Karapetjanz, M. K.: Osnovnie Termodinamitscheskie Konstanti, Izd. Khimia, Leningrad (1983).

27. Schick, H. L.: Thermodynamics of Certain Refractory Compounds II, Academic Press, New York and London (1966).

28. King, J. P., Cobble, H. W.: J. Am. Chem. Soc. 79, 1559 (1957).

29. Adilbisch, M., Zaitseva, N. G., Kovacs, Z., Novgorodov, A. F., Sergejev, Y. J., Tikhonov, V. I.: JINR Preprint P12-10584 Dubna (1977).

30. Franklin, J. E., Stickney, R. E.: High Temp. Sci. 3, 401411 (1971).

31. Dean, J. A.: Langes Handbook of Chemistry, 13th ed., 1973, p. $9-48$.

32. Battles, J. E., Gunderserson, B. E., Edwards, R. K.: J. Phys. Chem. 72, 3963 (1968).

33. Brewer, L.: Chem. Rev. 52, 2-75 (1953).

34. Daev, V. I., Smirnov, V. I.: Dokl. Akad. Nauk SSSR 140, 822 (1961).

35. Tribalat, S.: Rhenium. In: Nouveau Traite de Chimie Minérale, Paris (1960).

36. Resuchina, T. N., Gorschkova, T. J.: Zh. Fiz. Khim. 54, 2688 (1980).

37. Oppermann, H.: Z. Anorg. Allg. Chem. 523, 135-144 (1985).

38. Skinner, A. B., Searcy, A. W.: J. Phys. Chem. 77, 478/1578 (1973).

39. Gluschko: Thermitscheskie Konstanti Weschtschestv, Moskwa 1974 (VII).

40. Schäfer, H.: Z. Anorg. Allg. Chem. 400, 253 (1973).

41. Samsonov, G. V.: The Oxide Handbook, 2. ed., IFI/Plenum (1973).

42. Schoen, N. C., Orlov, G., McDonald, R. J.: Phys. Rev. C 20, 88 (1979).

43. Eichler, R., Eichler, B., Gäggeler, H. W., Türler, A.: PSIAnn. Rep., Annex IIIA, 59-61 (1997).

44. Domanov, V. P.: Doctoral thesis, Institute of Atomic Energy, Moscow (1984).

45. Türler, A.: Radiochim. Acta 72, 7-17 (1996).

46. Eichler, B., Zvara, I.: Radiochim. Acta 30, 233 (1982).

47. Zvara, I.: Radiochim. Acta 38, 95 (1982).

48. Eichler, B.: Radiochim. Acta 61, 81-90 (1993).

49. Eichler, B.: Radiochim. Acta 56, 133-140 (1992).

50. Vahle, A.: Doctoral thesis, TU Dresden (1995).

51. Düllmann, C., Eichler, B., Gäggeler, H. W., Türler, A.: PSIAnn. Rep., Annex III, 4 (1998).

52. Dressler, R., Türler, A., Jost, D. T., Piguet, D., Eichler, B., Gäggeler, H. W.: PSI-Ann. Rep., Annex IIIA, 87 (1994).

53. Eichler, R., Eichler, B., Gäggeler, H. W., Türler, A.: PSIAnn. Rep., Annex III, 83 (1996).

54. Eichler, B., Gäggeler-Koch, H., Gäggeler, H. W.: Radiochim. Acta 30, 233 (1979).

55. Eichler, B.: JINR Preprint P12-9454 Dubna (1976).

56. Eichler, B.: Kernenergie 19(10), 307 (1976). 
